\title{
The Effects of Soil-Applied Humic Substances to the Dry Weight and Mineral Nutrient Uptake of Maize Plants under Soil-Salinity Conditions
}

\author{
Murat A. TURAN', Barış B. AŞIK, Ali V. KATKAT, Hakan ÇELIKK \\ Uludag University, Faculty of Agriculture, Department of Soil Science and Plant Nutrition \\ Bursa,Turkey; maturan@uludag.edu.tr ('corresponding author)
}

\begin{abstract}
The aim of this study was to examine the effects of the soil application of humus substances on the dry weight and the nutrient uptake of selected elements in maize grown under salt stress in greenhouse conditions. Sodium chloride was added to the soil to obtain 0,15 , 30,45 or $60 \mathrm{mM} \mathrm{NaCl}$. Three different doses of solid humus $\left(0,1\right.$ or $\left.2 \mathrm{~g} \mathrm{~kg}^{-1}\right)$ were applied to the soil one month prior to planting. High levels of salt ( 45 and $60 \mathrm{mM} \mathrm{NaCl}$ ) had negative impacts on the dry weight and the $\mathrm{N}, \mathrm{P}, \mathrm{K}, \mathrm{Ca}, \mathrm{Mg}, \mathrm{Fe}, \mathrm{Cu}, \mathrm{Zn}$ and Mn uptake of the maize plants. The highest mean dry weight, $\mathrm{Mg}$ and $\mathrm{Mn}$ uptake were observed for the $1 \mathrm{~g}$ humus kg${ }^{-1}$ treatment and the highest mean $\mathrm{Cu}$ content was in the $2 \mathrm{~g}$ humus $\mathrm{kg}^{-1}$ treatment. On the contrary, the highest mean uptakes of $\mathrm{N}$ and $\mathrm{P}$ were found in the soils in which humic substances was not added. The interactions of $\mathrm{NaCl}$ and the soil humus content were significant for the uptake of $\mathrm{Cu}(\mathrm{p} \leq 0.01)$, and we found that adding humus increased the content of $\mathrm{Cu}$ in maize plants under slight salt stress $(15 \mathrm{mM} \mathrm{NaCl})(\mathrm{p} \leq 0.01)$.
\end{abstract}

Keywords: humic substances, maize, nutrient elements, salinity

\section{Introduction}

Soil salinity affects agricultural productivity in many parts of the world, particularly in irrigated lands (Allakhverdiev et al., 2000; Zörb et al., 2004). The genesis of saline soils may be natural or accelerated by the extension of irrigation in agricultural practices, the intensive use of water resources combined with high evaporation rates and human activity (Lambers, 2003; Arzani, 2008). In addition to uncontrolled irrigation, continuous cropping, excessive fertilization and poor-quality water may also cause salinity problems with reduction in the yield and quality of product (Maas and Grattan, 1999; Cansev and Ozgur, 2010).

Several studies have evaluated the effect of the organic matter content on the fertility of soils (Loveland and Webb, 2003; Pan et al., 2009). The humic substances, the major component of soil organic matter, have both direct and indirect effects on plant growth (Sangeetha et al., 2006). The direct effects are those that require the uptake of humic substances into the plant tissue resulting in various biochemical outcomes, whereas the indirect effects involve the improvement of soil properties, such as aggregation, aeration, permeability, water holding capacity, micronutrient transport and availability (Tan, 2003). Chen and Aviad (1990) and Varanini and Pinton (1995) have summarized the effects of humic substances on plant growth and mineral nutrition, pointing out the positive effects on seed germination, seedling growth, root initiation, root growth, shoot development and the uptake of macro and microelements.
The agricultural areas that are affected by salt need amendments, such as a determination of the most suitable salt-tolerant plant species or the application of different substances in order to reduce the effects of salinity (Bartels and Sunkar, 2005; Yamaguchi and Blumwald, 2005). Xudan (1986) and Kulikova et al. (2005) have indicated that humic substances might provide anti-stress effects to plants under abiotic stress conditions (i.e., unfavorable temperature, extreme $\mathrm{pH}$, and soil salinity) by reducing the uptake of some toxic elements.

Considering that salinity is a major problem in the cereal growing basins in Turkey there is a need to determine the effects of salinity and soil applications of humic substances on the growth of plants. In this context, the objective of the current study was to determine the relations between the application of humic substances and the growth/nutrient uptake of maize (Zea mays L.), a moderately salt-sensitive plant, under salt stress.

\section{Materials and methods}

The soil used in this study was collected from a depth of $0-20 \mathrm{~cm}$ of the field located in the Agricultural Research and Application Center of Uludag University, Bursa, Turkey. The soil was classified as Vertisol (Typic haploxerert) according to Soil Taxonomy and in the unit of Eutric Vertisol according to the FAO/UNESCO classification systems (Aksoy et al., 2001).

Selected physical and chemical properties of the soil were analyzed. The texture was determined using the hydrometer method (Tan, 2005). The $\mathrm{pH}$ and $\mathrm{EC}$ were mea- 
172

sured in a 1:2.5 water extract, and the lime content was determined according to Richards (1954). The organic matter content was analyzed according to the modified Walkley-Black method (Nelson and Sommers, 1982). Total nitrogen was determined with a Buchi K-437 / K-350 Digestion/Distillation Unit according to the metod of Kjeldahl (Bremmer, 1965). The available $\mathrm{P}$ was determined using a Shimadzu UV 1208 model spectrophotometer according to the method of Watanabe and Olsen (1965). Exchangeable cations $(\mathrm{Na}, \mathrm{K}, \mathrm{Ca}$ and $\mathrm{Mg}$ ) were extracted with ammonium acetate at $\mathrm{pH} 7.0$ (Jackson, 1958) and determined using an Eppendorf Elex 6361 model Flame Photometer. Available $\mathrm{Fe}, \mathrm{Cu}, \mathrm{Zn}, \mathrm{Mn}$ were extracted with DTPA $(0.005 \mathrm{M}$ DTPA $+0.01 \mathrm{M} \mathrm{CaCl}+0.1 \mathrm{M} \mathrm{TEA} \mathrm{pH}$ 7.3) (Lindsay and Norwell, 1978) and determined with a Philips PU9200x model Atomic Absorption Spectrophotometer. Selected chemical and physical properties of the soil used in this research are shown in Tab. 1. The soil used in the experiment had a neutral $\mathrm{pH}$, it was classified as sandy clay with a low salt and content, and the content of organic matter and was inadequate in terms of nitrogen, phosphorus and zinc.

Tab. 1. Physical and chemical properties of the soil

\begin{tabular}{cccc}
\hline Texture & $\begin{array}{c}\text { Sandy } \\
\text { clay }\end{array}$ & \multicolumn{2}{c}{$\begin{array}{c}\text { Exchangeable cations, } \\
\text { me 100g-1 }\end{array}$} \\
\hline Sand, \% & 45.15 & Sodium $(\mathrm{Na})$ & 0.17 \\
\hline Silt, \% & 15.22 & Potassium $(\mathrm{K})$ & 0.45 \\
\hline Clay, \% & 39.63 & Calcium $(\mathrm{Ca})$ & 19.26 \\
\hline $\mathrm{pH}$ & 7.24 & Magnesium $(\mathrm{Mg})$ & 2.35 \\
\hline $\mathrm{EC}, \mathrm{mS} \mathrm{cm}^{-1}$ & 0.83 & Available microelements, $\mathrm{mg} \mathrm{kg}^{-1}$ \\
\hline $\mathrm{CaCO}_{3}, \%$ & 0.22 & Iron $(\mathrm{Fe})$ & 5.56 \\
\hline $\begin{array}{c}\text { Organic matter, \% } \\
\text { Total nitrogen (N), \% }\end{array}$ & 1.30 & Copper $(\mathrm{Cu})$ & 1.30 \\
\hline $\begin{array}{c}\text { Available phosphorus } \\
\text { (P), } \mathrm{mg} \mathrm{kg}^{-1}\end{array}$ & 7.08 & Zinc $(\mathrm{Zn})$ & 0.20 \\
\hline
\end{tabular}

The experiment was conducted in a greenhouse in a completely randomized factorial design with three soil application doses of humus, 0 (control) 1 or $2 \mathrm{~g} \mathrm{~kg}^{-1}$, and five $\mathrm{NaCl}$ doses, 0 (control), 15, 30, 45 or $60 \mathrm{mM}$. Each application consisted of three replications. The humus that was used obtained from Delta Chemicals Co. (Ankara, Turkey) and was a derivate of leonardite $(65 \% \mathrm{w} / \mathrm{w}, \mathrm{pH}$ 4.87, EC: $5.80 \mathrm{mS} \mathrm{cm}^{-1}$ ) and commercially known as Deltahumus.

Air-dried soil samples were passed through a $4 \mathrm{~mm}$ sieve. For humus applications, Deltahumus was placed into a large bowl and the total weight of the soil was adjusted to $5 \mathrm{~kg}$. The mixture was homogenized and put into polyethylene covered plastic pots. Sodium choride was added to the pots according to the final salt levels and the pots were incubated for 30 days. As a basal fertilizer, nitrogen $\left(100 \mathrm{mg} \mathrm{kg}^{-1}\right.$, as $\left.\mathrm{NH}_{4} \mathrm{NO}_{3}\right)$, phosphorus $\left(80 \mathrm{mg} \mathrm{kg}^{-1}\right)$, potassium $\left(100 \mathrm{mg} \mathrm{kg}^{-1}\right.$, as $\left.\mathrm{KH}_{2} \mathrm{PO}_{4}\right)$, zinc $\left(0.5 \mathrm{mg} \mathrm{kg}^{-1}\right.$, as $\mathrm{ZnSO}_{4}$ ) were applied to the pots before planting. Six maize (Zea mays L. 'Fleuri AG 92149') seeds were sown into each pot which was thinned to four after emergence which had a diameter of $20 \mathrm{~cm}$ and a depth of $18 \mathrm{~cm}$. All pots were irrigated with deionized water during the experiment.

After two months of vegetative growth, the plants were harvested, dried at $65^{\circ} \mathrm{C}$ and the dry weights were determined. The plant samples were wet digested by using a $\mathrm{HNO}_{3}+\mathrm{HCIO}_{4}(4: 1)$ mixture. The nitrogen level was determined by the Kjeldahl method (Bremmer, 1965), and the $\mathrm{P}$ was determined by the vanadomolybdophosphoric acid method using a spectrophotometer (Kacar and Inal, 2008). The $\mathrm{K}, \mathrm{Na}$ and $\mathrm{Ca}$ values were determined by flame emission (Horneck and Hanson, 1998). The contents of $\mathrm{Mg}, \mathrm{Fe}, \mathrm{Mn}, \mathrm{Zn}$ and $\mathrm{Cu}$ were determined by atomic absorption spectrometry (Philips PU 9200x, Pye Unicam Ltd. GB) (Hanlon, 1998).

The pot experiment was arranged in a completely randomized design (CRD) with three soil application doses of humus, five $\mathrm{NaCl}$ doses and three replicates $(\mathrm{n}=45)$. Analysis of variance (ANOVA) of data for all parameters was computed using TARIST computer package (Tarist, 1994). The mean values were grouped with LSD multiple range test $(\mathrm{p} \leq 0.01)$.

\section{Results and discussion}

\section{The effects of $\mathrm{NaCl}$ on plant growth and the uptake of plant nutrients}

The effects of the soil application of humus on plant growth, the uptake of mineral nutrients and their interactions with $\mathrm{NaCl}$ levels are given in Tab. 2, 3 and 4. According to the results, an increase in the $\mathrm{NaCl}$ level gradually decreased the growth, expressed as dry weight, of the maize plant (Tab. 2). Reductions in dry weight, even at the

Tab. 2. The effects of soil application of humus on plant dry weight under increasing $\mathrm{NaCl}$ levels $\left(\mathrm{g} \mathrm{pot}^{-1}\right)$

\begin{tabular}{|c|c|c|c|c|c|c|c|}
\hline \multirow{3}{*}{$\begin{array}{c}\mathrm{NaCl} \mathrm{mM} \\
0\end{array}$} & \multicolumn{7}{|c|}{ Humus levels, $\mathrm{g} \mathrm{kg}^{-1}$} \\
\hline & \multicolumn{2}{|c|}{0} & \multicolumn{2}{|l|}{1} & \multirow{2}{*}{$\begin{array}{r}2 \\
21.53\end{array}$} & \multicolumn{2}{|c|}{ Mean } \\
\hline & 21.94 & & 24.22 & & & 22.56 & $\mathrm{a}$ \\
\hline 15 & 22.51 & & 21.27 & & 20.33 & 21.37 & a \\
\hline 30 & 18.08 & & 17.73 & & 14.97 & 16.93 & b \\
\hline 45 & 15.96 & & 14.46 & & 13.11 & 14.51 & c \\
\hline 60 & 10.77 & & 12.79 & & 11.06 & 11.54 & d \\
\hline Mean & 17.85 & A & 18.09 & A & 16.20 & $\mathrm{~B}$ & \\
\hline Humus $\mathrm{LSD}_{0}$ & 1.277 & & $\mathrm{NaCl} \mathrm{LSD}$ & 0.01 & & Humus x $\mathrm{Na}$ & Ins \\
\hline
\end{tabular}

The differences between values indicated by different letters are significant.

Capital letters indicate rows and small letters indicate columns. ns: not significant 


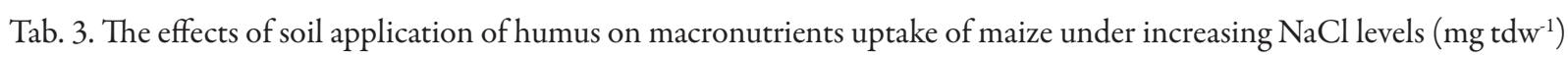

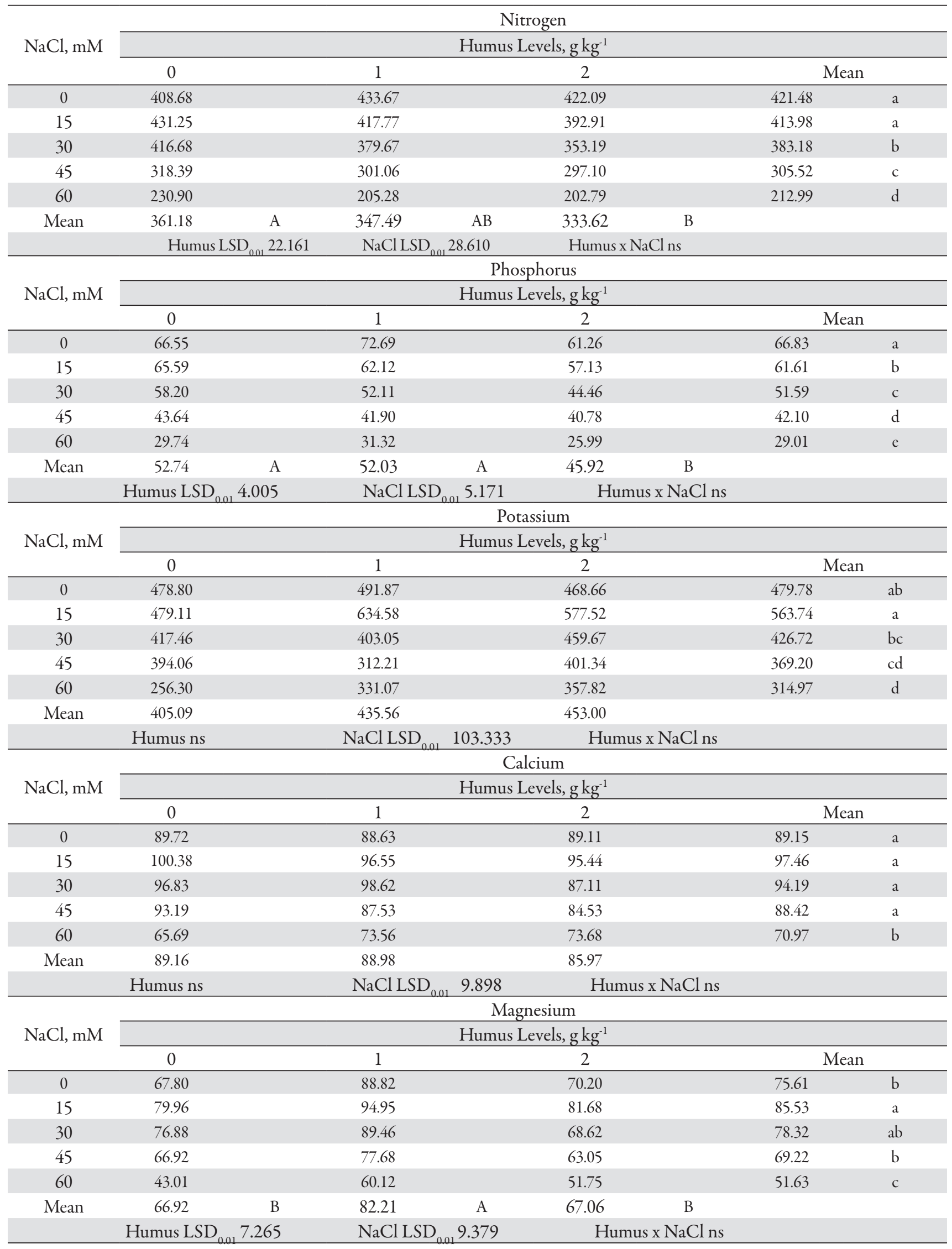


174

Tab. 4. Effects of soil application of humus on micronutrients uptake of maize under increasing $\mathrm{NaCl} \mathrm{levels}\left(\mathrm{mg} \mathrm{tdw}^{-1}\right)$

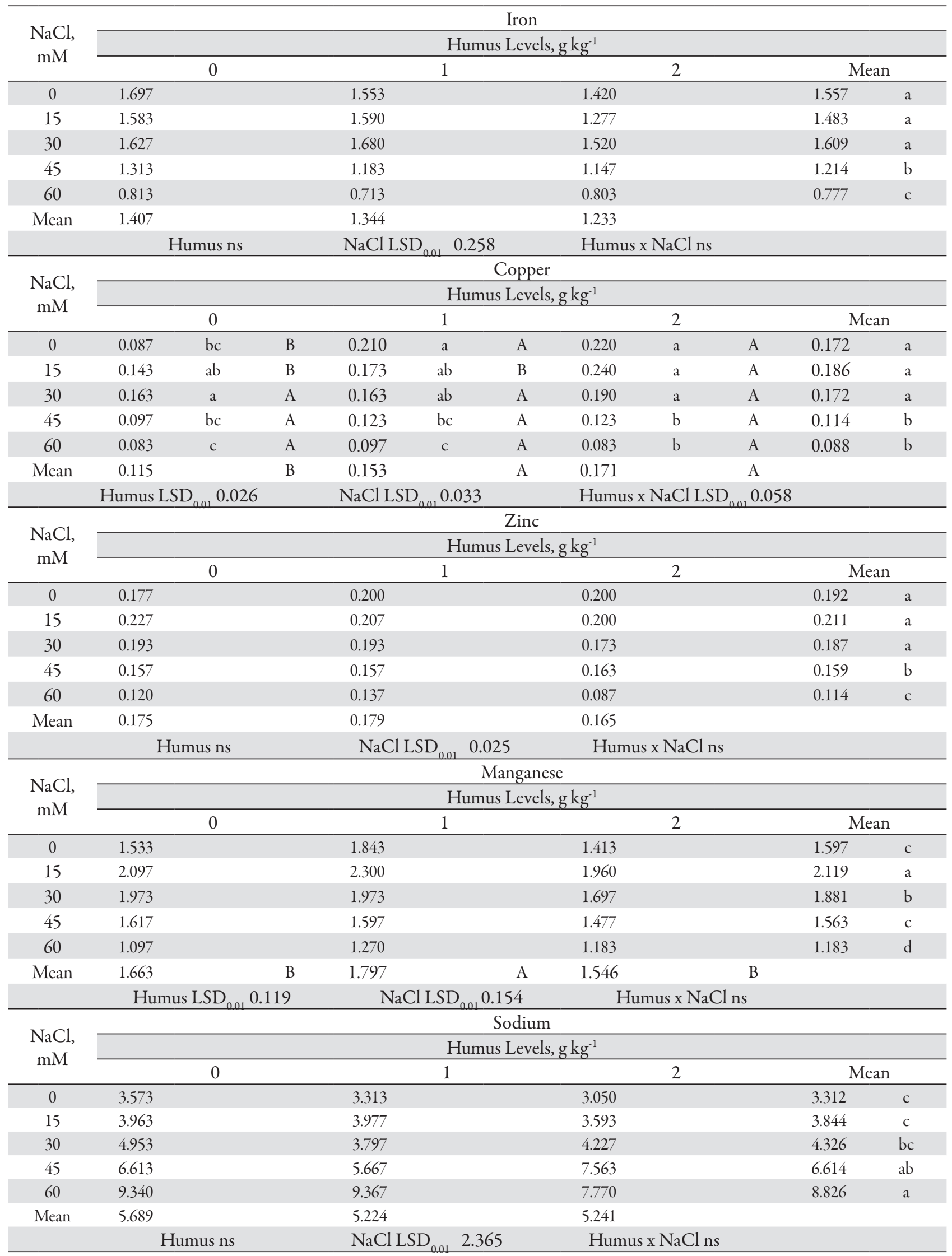

The differences between values indicated by different letters are significant. Capital letters indicate rows and small letters indicate columns. ns: not significant 
lowest level of $\mathrm{NaCl}$, were observed as $5.27 \%$. The applications of higher $\mathrm{NaCl}$ concentrations had negative effects on the uptakes of $\mathrm{N}, \mathrm{P}, \mathrm{K}, \mathrm{Ca}, \mathrm{Mg}, \mathrm{Fe}, \mathrm{Cu}, \mathrm{Mn}$ and $\mathrm{Zn}$ in maize; except for $\mathrm{Na}$ (Tab. 3 and 4). The decreases in the dry weight and uptake of mineral elements in the plants were evident particularly at the 45 and $60 \mathrm{mM}$ of $\mathrm{NaCl}$ levels.

The salinity of the soil is a critical factor in plant production, as an excess of salts leads to both osmotic and ionic stresses that suppress plant growth and nutrient uptake (Grattan and Grieve, 1999; Benlloch and Gonzalez, 2005; Turan et al., 2007a, b; 2010; Dhanapackiam and Muhammed Ilyas, 2010). In the present study, it has been observed a significant reduction in the growth of maize plants associated with increasing $\mathrm{NaCl}$ concentrations.

Salinity affects both water absorption and biochemical processes resulting in reduction of plant growth, particularly due to a decline in the rates of net photosynthesis, negative effect on the $\mathrm{CO}_{2}$ assimilation and excessive decrease in nutrient uptake (Parida and Das, 2005; Cha-Um and Kirdmanee, 2009).

Many researchers have reported that treatment of low levels of $\mathrm{NaCl}$ reduce the dry weight of experimental plants (Al-Karaki, 1997; Taban et al., 1999). The results obtained in our study were similar to these findings for low levels of $\mathrm{NaCl}$, however, it has been found that high levels of $\mathrm{NaCl}(30,45$ and $60 \mathrm{mM})$ significantly inhibited the growth of the maize plants (Khan et al., 2000; Asik et al., 2009). Salinity is known to reduce the $\mathrm{N}$ accumulation (Alam, 1994; Turan et al., 2007a, b), the P concentrations (Navarro et al., 2001) and the uptake of K in plants (Lopez and Satti, 1996). High $\mathrm{Na}$ also has an antagonistic effect on the uptake of $\mathrm{Ca}$ and $\mathrm{Mg}$, most likely caused by the displacement $\mathrm{Ca}$ and $\mathrm{Mg}$ by $\mathrm{Na}$ in the cellular membranes of the root (Yermiyahu et al., 1997). Under salt stress, the solubility of micronutrients is particularly low, and plants grown in these soils often show mineral deficiencies. Furthermore, these detrimental effects are generally observed at the whole plant level (Francois and Maas, 1999).

\section{The effects of the soil application of humus on plant growth and the uptake of plant nutrients}

The soil application of humus was significantly effective on dry weight and on the uptakes of $\mathrm{N}, \mathrm{P}, \mathrm{Mg}, \mathrm{Cu}$ and $\mathrm{Mn}$ (Tab. 3 and 4). The highest mean dry weight and uptakes of $\mathrm{Mg}$ and $\mathrm{Mn}$ were obtained with $1 \mathrm{~g}^{\text {humus } \mathrm{kg}^{-1}}$ treatment (82.21 and $\left.1.797 \mathrm{mg} \mathrm{pot}^{-1}\right)$, and the highest amount of $\mathrm{Cu}\left(0.171 \mathrm{mg} \mathrm{pot}^{-1}\right)$ was obtained with $2 \mathrm{~g}_{\text {humus }} \mathrm{kg}^{-1}$ treatment. On the contrary, the highest means for the uptakes of $\mathrm{N}$ and $\mathrm{P}, 361.18$ and $52.74 \mathrm{mg} \mathrm{pot}^{-1}$, respectively, were determined at the dose of $0 \mathrm{~g} \mathrm{~kg}^{-1}$ of humus (Tab. 3).

Chen and Aviad (1990), Fagbenro and Agboda (1993) and David et al. (1994) have reported that the addition of humic substances, which act in a similar way to growth hormones, promoted the growth and nutrient uptake of plants. Plants are able to take up more mineral elements due to an increased membrane permeability, and a betterdeveloped root system facilitates the transport of elements within the roots (Zientara, 1983).

Regardless, there is little available literature regarding the application of humic acid and its effects on salinity tolerance in plants. Liu (1998) has reported that a treatment of humic acid under salt stress did not increase the uptake of N, P, K or Ca; however, Asik et al. (2009), have stated that a high humic acid treatment did have a slight effect. In the present study, the uptake of minerals was negatively affected with the $2 \mathrm{~g}$ humus $\mathrm{kg}^{-1}$ treatment, in accordance with Arancon et al. (2006); that this was likely due to the levels of treatments, the growth medium and the origin of the humic substance.

\section{The interaction of humic substances with salt stress}

The interaction between the application of humic substances and $\mathrm{NaCl}$ to the soil was found significant only for the $\mathrm{Cu}$ uptake $(\mathrm{p}<0.01)$ in the maize plants. The effects on the dry weight and the uptake of other nutrients were not significant. The highest uptake of $\mathrm{Cu}\left(0.240 \mathrm{mg} \mathrm{pot}^{-1}\right)$ was obtained in the treatment of $2 \mathrm{~g}$ humus kg-1 $+15 \mathrm{mM}$ $\mathrm{NaCl}$ (Tab. 4).

Although treatment of the soil with $\mathrm{NaCl}$ decreased the dry weight and the uptake of nutrients, the soil humus treatments ameliorated this decrease, particularly under the treatment of $60 \mathrm{mM}$ of $\mathrm{NaCl}$. Therefore, can be conclude that treatment of the soil with humus enhanced the uptake of nutrients in plant under conditions of 45 and 60 $\mathrm{mM} \mathrm{NaCl}$ (Tab. 3 and 4).

\section{Conclusions}

Humic substances, which are generally associated with natural organic compounds comprising 50 to $90 \%$ of the organic matter of peat, lignites, sapropels and the nonliving organic matter of soil and water ecosystems, can significantly reduce water evaporation and increase water availability to plants in non-clay, arid and sandy soils. Humic substances can help to improve unfavourable soil properties, plant productivity and nutrient uptake. Humic substances, holds positively charged molecules of soil surface that can be absorbed by the plant's roots and helps to improve micronutrient exchange. These benefits of humic substances may only be apperent under defined doses, thus the determination of the treatment dose is crucial under saline conditions. According to our data, the limit of application should not exceed $1 \mathrm{~g}$ humus kg-1 in the soil.

\section{Acknowledgments}

This study was supported by the Research Fund of The Uludag University Project No. 2003/92 and The Scientific and Technical Research Council of Turkey (TOVAG 105 O 345). 
176

\section{References}

Alam SM (1994). Nutrient by Plants Under Stress Conditions, p. 227-246. In: Pessarakli M (Ed.). Handbook of plant and crop stress. Marcel Dekker, New York.

Al-Karaki GN (1997). Barley response to salt stress at varied levels of phosphorus. J Plant Nutr 20:1635-1643.

Allakhverdiev SI, Sakamoto A, Nishiyama Y, Inaba M, Murata $\mathrm{N}$ (2000). Ionic and osmotic effects of $\mathrm{NaCI}$-induced inactivation of photosystems I and II in Synechococcus sp. Plant Physiol 123:1047-1056.

Aksoy E, Dirim MS, Tumsavas Z, Ozsoy G (2001). Formation of Uludag University campus soils: physical, chemical characteristics and classification. UU Res Projects Fond Project No. 98/32 Bursa.

Arancon NQ, Edwards CA, Lee S, Byrne R (2006). Effects of humic acids from verrnicomposts on plant growth. Eur J Soil Biol 42:65-69.

Arzani A (2008). Improving salinity tolerance in crop plants: A biotechnological view. Vitro Cell Dev Biol Plant 44:373383.

Asik BB, Turan MA, Celik H, Katkat VA (2009). Effect of humic substances on plant growth and mineral nutrients uptake of wheat (Triticum durum cv. 'Salihli') under conditions of salinity. Asian J Crop Sci 1:87-95.

Bartels D, Sunkar R (2005). Drought and salt tolerance in plants. Crit Rev Plant Sci 24:23-58.

Benlloch-Gonzalez M, Fournier J, Ramos J, Benlloch M (2005). Strategies underlying salt tolerance in halophytes are present in Cynara cardunculus. Plant Sci 168:653-659.

Bremmer JM (1965). Total Nitrogen, p. 1149-1178. In: Black CA (Ed.). Methods of soil analysis, part 2. American Soc Agric Inc, USA.

Cansev A, Ozgur M (2010). Grafting cucumber seedlings on Cucurbita spp.: Comparison of different grafting methods, scions and their performance. J Food Agric Env 8:804-809.

Cha-Um S, Kirdmanee C (2009). Effect of salt stress on proline accumulation, photosynthetic ability and growth characters in two maize cultivars. Pak J Bot 41:87-98.

Chen Y, Aviad T (1990). Effect of Humic Substances on Plant Growth, p. 161-187. In: MacCarthy P, Clapp CE, Malcolm RL, Bloom PR (Eds.). Humic substances in soil and crop sciences: selected reading. Soil Science Society Am, Madison.

David PP, Nelson PV, Sanders DC (1994). A humic acid improves growth of tomato seedling in solution culture. J Plant Nutr 17:173-184.

Dhanapackiam S, Muhammed Ilyas MH (2010). Effect of $\mathrm{NaCl}$ salinity on growth, nodulation and total nitrogen in Sesbania grandiflora. Indian J Sci Tech 3:87-89.

Fagbenro JA, Agboda AA (1993). Effect of different levels of humic acid on the growth and nutrient uptake of teak seedings. J Plant Nutr 16:1465-1483.
Francois L, Maas EV (1999). Crop Response and Management of Salt-Affected Soils, p. 169-203. In: Pessarakli M (Ed.). Handbook of plant and crop stress. Marcel Dekker, USA.

Grattan SR, Grieve CM (1999). Salinity-mineral nutrient relations in horticultural crops. Sci Hortic 78:127-157.

Hanlon EA (1998). Elemental Determination by Atomic Absorption Spectrophotometry, p. 157-164. In: Karla YP (Ed.). Handbook of reference methods for plant analysis. CRC Press, USA.

Horneck DA, Hanson D (1998). Determination of Potassium and Sodium by Flame Emission Spectrophotometry, p. 157 164. In: Karla YP (Ed.). Handbook of reference methods for plant analysis, CRC Press, USA.

Jackson M (1958). Soil Chemical Analysis. Prentice-Hall, Inc. Englewood Cliffs, New Jersey.

Kacar B, Inal A (2008). Plant Analysis. Nobel Publication, Ankara.

Khan MA, Ungar IA, Showalter AM (2000). Effects of salinity on growth, water relations and ion accumulation of the subtropical perennial halophyte Atriplex griffthii var. stocksii Ann Bot 85:225-232.

Kulikova NA, Stepanova EV, Koroleva OV (2005). Mitigating Activity of Humic Substances: Direct Influence on Biota, p. 285-309. In: Perminova IV (Ed.). Use of humic substances to remediate polluted environments: from theory to practice, NATO Science Series IV: Earth and Environmental Series. Kluwer Academic Publishers, USA.

Lambers H (2003). Dryland salinity: A key environmental issue in Southern Australia. Plant Soil 257:5-7.

Liu C (1998). Effects of humic substances on creeping bentgrass growth and stress tolerance., North Carolina State Univ., PhD Thesis, Philosophy Department of Crop Science

Lindsay WL, Norwell WA (1978). Development of a DTPA soil test for zinc, iron, manganese and copper. Soil Sci Soc Am J 42:421-428.

Loveland P, Webb J (2003). Is there a critical level of organic matter in the agricultural soils of temperate regions: a review. Soil Tillage Res 70:1-18.

Lopez MV, Satti SME (1996). Calcium and potassium-enhanced growth and yield of tomato under sodium-chloride stress. Plant Sc 114:19-27.

Maas EV, Grattan SR (1999). Crop Yields as Affected by Salinity, p. 55-108. In: Skaggs RW, Van Schilgaarde J (Eds.). Agricultural drainage. Agronomy Monograph 38, Am. Soc. Agron., Madison, WI, USA.

Masciandaro G, Ceccanti B, Ronchi V, Benedicto S, Howard L (2002). Humic substances to reduce salt effect on plant germination and growth. Commun Soil Sci Plant Anal 33:365-378.

Nelson DW, Sommers LE (1982). Total Carbon, Organic Carbon and Organic Matter, p. 539-579. In: Page AL, Miller RH, Keeney DR (Eds.). Methods of soil analysis part 2. chemical and microbiological properties, $2^{\text {nd }} \mathrm{Ed}$. 
American Society of Agronomy/Soil Science Society of America, Madison.

Navarro JM, Botella MA, Cerda A, Martinez V (2001). Phosphorus uptake and translocation in salt-stressed melon plants. J Plant Physiol 158:375-381.

Pan G, P Smith, Pan W (2009). The role of soil organic matter in maintaining the productivity and yield stability of cereals in china. Agric Ecosystems Environment 129: 344-348.

Parida AK, Das AB (2005). Salt tolerance and salinity effects on plants: A rev. Ecotoxicol Environ Safety 60:324-349.

Richards LA (1954). Diagnosis and Improvement of Saline and Alkali Soils. United State Department of Agriculture, Agriculture Handbook No. 60.

Sangeetha M, Singaram P, Devi RD (2006). Effect of lignite humic acid and fertilizers on the yield of onion and nutrient availability. Proceedings of $18^{\text {th }}$ World Congress of Soil Science July 9-15, Philadelphia, Pennsylvania, USA.

Taban S, Gunes A, Alpaslan M, Ozcan H (1999). Sensibility of various maize (Zea mays L. cvs.) varieties to salinity. Tr J Agric For 23:625-633.

Tan KH (2003). Humic Matter in Soil and Environment, Principles and Controversies. Marcel Dekker, Inc., Madison, New York.

Tan KH (2005). Soil Sampling, Preparation, and Analysis. $2^{\text {nd }}$ Ed. Marcel Dekker, Inc., New York.

Tarist (1994). General statistic, Version 4.01. DOS, Serial No: A1001, Egean Forestry Research Inst. Egean Univ. Agric. Faculty Field Crop Dept. Izmir.

Turan MA, Türkmen N, Taban S (2007a). Effect of $\mathrm{NaCl}$ on stomatal resistance and proline, chlorophyll, $\mathrm{Na}, \mathrm{Cl}$ and $\mathrm{K}$ concentrations of lentil plants J Agron 6:378-381.
Turan MA, Katkat AV, Taban S (2007b). Variations in proline, chlorophyll and mineral elements contents of wheat plants grown under salinity stress. J Agron 6:137-141.

Turan MA, Elkarim AHA, Taban N, Taban S (2010). Effect of salt stress on growth and ion distribution and accumulation in shoot and root of maize plant. African J Agric Res 5:584588.

Varanini Z, Pinton R (1995). Humic substances and plant nutrition. Prog Bot 56:97-117.

Watanabe FS, Olsen SR (1965). Test of an ascorbic acid method for determining phosphorus in water and $\mathrm{NaHCO}_{3}$ extracts from soil. Soil Sci Soc Am Proc 29:677-678.

Xudan X (1986). The effect of foliar application of fulvic acid on water use, nutrient uptake and wheat yield. Aust J Agric Res 37:343-350.

Yermiyahu U, Nir S, Ben-Hayyim G, Kafkafi U, Kinraide B (1997). Root elongation in saline solution related to calcium binding to root cell plasma membranes. Plant Soil 191:6776.

Yamaguchi T, Blumwald E (2005). Developing salt-tolerant crop plants: challenges and opportunities. Trends Plant Sci 10:615-620.

Zientara M (1983). Effect of sodium humate on membrane potential in internodal cells of Nitellopsis obtuse. Acta Societatis Botanicorum Poloniae 52:271-277.

Zörb C, Schmitt S, Neeb A, Karl S, Linder M, Schubert S (2004). The biochemical reaction of maize (Zea mays L.) to salt stress is characterized by a mitigation of symptoms and not by a specific adaptation. Plant Science 167:91-100. 